\title{
PATTERNS OF GALL-FORMING IN Ossaea confertiflora (MELASTOMATACEAE) BY Lopesia brasiliensis (DIPTERA: CECIDOMYIIDAE) IN AN AREA OF ATLANTIC RAINFOREST IN SOUTHEASTERN BRAZIL
}

\author{
VRCIBRADIC, D., ${ }^{1}$ ROCHA, C. F. D. ${ }^{1}$ and MONTEIRO, R. F. ${ }^{2}$ \\ ${ }^{1}$ Setor de Ecologia, Instituto de Biologia, Universidade do Estado do Rio de Janeiro, Rua S. Francisco Xavier, 524, \\ CEP 20550-011, Maracanã, Rio de Janeiro, RJ, Brazil \\ ${ }^{2}$ Laboratório de Ecologia de Insetos, Instituto de Biologia, Universidade Federal do Rio de Janeiro, C.P. 68020, \\ CEP 21941-970, Ilha do Fundão, Rio de Janeiro, RJ, Brazil \\ Correspondence to: Carlos Frederico D. Rocha, Setor de Ecologia, Instituto de Biologia, Universidade do \\ Estado do Rio de Janeiro, Rua S. Francisco Xavier, 524, CEP 20550-011, Maracanã, Rio de Janeiro, \\ RJ, Brazil, e-mail: cfdrocha@uerj.br \\ Received November 17, 1998 - Accepted February 01, 1999 - Distributed February 28, 2000
}

(With 3 figures)

\begin{abstract}
Patterns of galling by the gall midge Lopesia brasiliensis (Diptera: Cecidomyiidae) were studied in Ossaea confertiflora (Melastomataceae) in an Atlantic forest site at Ilha Grande, RJ. Out of the 81 plants surveyed, $55(67.9 \%)$ bore galls. The number of galls per galled individual ranged from 1 to 261 and $94.4 \%$ of the galls were in leaves. The number of galls per galled leaf varied from 1 to 25 . Total gall number was positively correlated with plant height. Larger and more ramified plants tended to have a smaller percentage of their leaves with galls and a lower density of galls per leaf than smaller plants. Plants that were close to other individuals of the same species tended to have more galls per leaf than relatively isolated plants. The observed patterns may be linked to strategies of optimization in the use of resources (i.e. oviposition sites) and predation avoidance by the gall midges.
\end{abstract}

Key words: Cecidomyiidae, Ilha Grande, leaf galls, Lopesia brasiliensis, Ossaea confertiflora.

\section{RESUMO}

Padrões de galhamento em Ossaea confertiflora (Melastomataceae) por Lopesia brasiliensis (Diptera: Cecidomyiidae) em uma área de Floresta Atlântica no Sudeste do Brasil

Foram estudados os padrões de galhamento em Ossaea confertiflora (Melastomataceae) por Lopesia brasiliensis (Diptera: Cecidomyiidae) em uma área de floresta Atlântica na Ilha Grande, RJ. Das 81 plantas amostradas, $55(67.9 \%)$ estavam galhadas. O número de galhas presente em cada indivíduo variou de 1 a 261 e 94,4\% destas encontrava-se nas folhas. O número de galhas em cada folha variou de 1 a 25 . O número total de galhas esteve positivamente correlacionado com a altura da planta. Houve uma tendência a plantas maiores e mais ramificadas terem uma porcentagem menor de suas folhas galhadas e menor densidade de galhas por folha do que plantas menores. Plantas próximas a outras da mesma espécie tenderam a apresentar mais galhas por folhas do que plantas relativamente isoladas. Os padrões observados podem estar ligados a estratégias de otimização no uso de recursos (isto é, sítios de oviposição) e proteção da prole pelos galhadores.

Palavras-chave: Cecidomyiidae, galhas foliares, Ilha Grande, Lopesia brasiliensis, Ossaea confertiflora. 


\section{INTRODUCTION}

Galls are probably the most familiar examples of parasitism in plants by animals. However, the interactions between gall-forming insects and their host plants are still insufficiently understood (e.g. Craig et al., 1989; Fay et al., 1996; Thompson, 1988). Factors such as the growth rate and structural complexity of the host plant, as well as quantitative and qualitative aspects of the available resources (i.e. plant tissues) are of prime importance to galling insects, since they respond to them at the moment of oviposition (Lawton, 1983; Price et al., 1990; Strong et al., 1984).

The choice of the oviposition sites by the gallformers within a population of host plants, or within a single individual in that population, has a fundamental role for the survival and development of the larvae (e.g. Craig et al., 1989; Denno \& McClure, 1983; Fernandes \& Price, 1991; Preszler \& Price, 1988; Whitham, 1980), which develop entirely inside the gall, leaving it only after they had reached the adult stage. Moreover, the degree of complexity in host plant architecture (i.e. a combination of plant height, number of shoots and leaves and crown volume) is known to influence directly the diversity and density of their associated fauna of phytophagous insects (e.g. Lawton, 1983; Dansa \& Rocha, 1992; Collevatti \& Sperber, 1997).

Although a reasonable amount of information on the gallformer-host plant relationships in temperate regions exist in the literature, such relationships are still little studied in the tropics, and especially in the Neotropics, though the number of studies in this region has increased recently (e.g. Ferreira et al., 1990; Fernandes et al., 1987, 1988, 1997; Fernandes \& Price, 1991, 1992; Lara \& Fernandes, 1994; Collevatti \& Sperber, 1997; Ribeiro et al., 1998).

The main cecidogenous agents in the Neotropical region are dipterans of the family Cecidomyiidae (Houard, 1933). Cecidomyiids induce gall-forming on pratically all kinds of plant organs, but predominantly on leaves (Mani, 1964; Fernandes et al., 1988; Monteiro et al., 1994).

Ossaea confertiflora (Melastomataceae) is a perennial shrub that is frequently found in disturbed areas, clearings and forest edges, and occasionally also on trails inside primary forest.
This species, common in Atlantic Rainforest areas, is host to the gall-midge Lopesia brasiliensis Rübsaamen (Cecidomyiidae), which induces conspicuous reddish, hairy, round, unilocular galls ca. $5 \mathrm{~mm}$ in diameter on its leaves (Fig. 1) and, occasionally, also on petioles (Gagné, 1994). In the present study, we analyse the patterns of frequency and intensity of gall-forming within and among individuals of $O$. confertiflora in an area of Atlantic Rainforest and evaluate how they are influenced by factors such as height, structural complexity and relative isolation (regarding proximity to other conspecifics) of individual host plants.

\section{MATERIAL AND METHODS}

\section{Study Area}

This study was carried out during November 1996 in an area of Atlantic Rainforest near Vila Dois Rios in Ilha Grande $\left(23^{\circ} 15^{\prime} \mathrm{S} ; 4^{\circ} 15^{\prime} \mathrm{W}\right)$, an island on the coast of Rio de Janeiro State, SE Brazil. The area is covered by Atlantic Rainforest with different levels of regeneration, due to disturbances caused by sucessive decades of human activities (remnants of undisturbed primary forest are present in the central areas of the island). Annual rainfall and mean annual temperature in the area are $1,700 \mathrm{~mm}$ and $23^{\circ} \mathrm{C}$, respectively (Araújo \& Oliveira, 1988).

\section{Procedures}

We examined and marked 81 plants, randomly sampled, along two trails on a patch of second-growth forest. For each, we recorded its height (in $\mathrm{cm}$, with a measuring tape), number of bifurcations (branchings) and distance from the nearest conspecific (plants without conspecifics within a 5-meter or greater radius were considered as 'isolated'). Each plant was checked for the presence of Lopesia galls and we counted the total number of galls per plant, number of galls per galled leaf, and number of galled leaves. As the total number of leaves per plant was not counted, the relative frequency of galled leaves of each plant was estimated by dividing its number of galled leaves by its number of ramifications (i.e. number of bifurcations +1 ), obtaining an index of galled leaves per \# of ramifications (or frequency of galled leaves - FGL). 


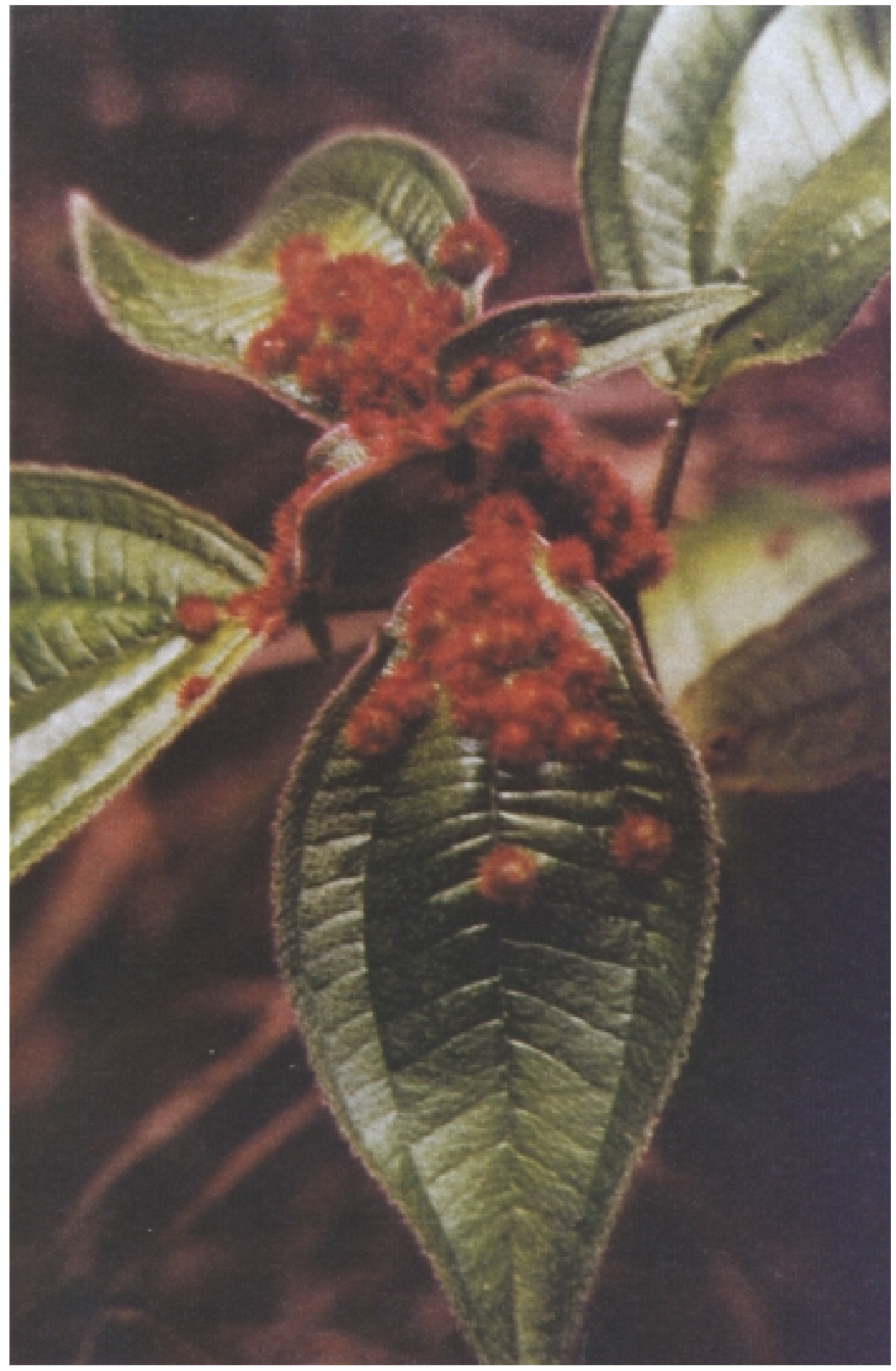

Fig. 1 - Aspect of Lopesia brasiliensis galls on the leaves of Ossaea confertiflora at Ilha Grande, Rio de Janeiro. 
Total gall number, FGL, and number of galls per leaf (NGL) were each correlated with plant height and number of ramifications through correlation analyses. Frequency of galled plants were compared between isolated and non-isolated plants and among plants of different size (height) classes (i.e. class 1 - up to $40 \mathrm{~cm}$; class $2-41$ $80 \mathrm{~cm}$; class 3 - over $80 \mathrm{~cm}$ ) using a chi-square test. FGL and NGL was compared among size classes using analyses of variance (one-way ANOVA) and between isolated and non-isolated plants using analyses of covariance (ANCOVA), with plant height as covariate (Zar, 1984). Descriptive statistics presented throughout the text refer to mean \pm one standard deviation.

\section{RESULTS}

Of the 81 sampled individuals of $O$. confertiflora, 55 (67.9\%) bore Lopesia galls, with a range of 1 to 261 galls per plant. We found no other types of galls on the leaves of those plants. Lopesia galls were mostly on leaves (94.4\%), and rarely on petioles or buds. The number of galled leaves per host plant ranged from 1 to 54 and the number of galls per galled leaf ranged from 1 to $25($ mean $=2.77 \pm 3.0$ galls/leaf $)$. Most of the 529 galled leaves surveyed bore one $(47.6 \%)$, two $(18.3 \%)$ or three $(11.9 \%)$ galls. Frequently, galls of different sizes and developmental stages were found in the same plant and, sometimes, on the same leaf.

Plant height ranged from 12 to $140 \mathrm{~cm}$ $($ mean $=59.8 \pm 30.6 \mathrm{~cm})$ and was significantly correlated with number of ramifications $(\mathrm{r}=0.72$, $\mathrm{p}<0.05)$. Plant height did not differ between galled and non-galled plants (ANOVA; $\mathrm{F}_{1,78}=1.66, \mathrm{p}=$ 0.2 ). Among galled plants, total number of galls per plant was positively and significantly correlated with plant height $(\mathrm{r}=0.295, \mathrm{p}<0.05, \mathrm{n}=55)$, which explained $8.7 \%$ of the variation in gall number (Fig. 2). However, it was not significantly correlated with number of branchings $(r=0.173$, $\mathrm{p}=0.21, \mathrm{n}=54)$, nor with the summed effect of both variables $\left(\mathrm{r}^{2}=0.088, \mathrm{p}=0.096, \mathrm{n}=54\right)$.

The total number of galled leaves per plant was positively and significantly correlated with plant height $(\mathrm{r}=0.556, \mathrm{p}<0.001, \mathrm{~N}=53)$, with number of ramifications $(\mathrm{r}=0.47, \mathrm{p}<0.001, \mathrm{~N}=$ 53 ), and with the additive effect of both variables $\left(\mathrm{r}^{2}=0.323, \mathrm{p}<0.001, \mathrm{~N}=53\right)$. The index FGL had a negative correlation with number of bifurcations, plant height, and the summed effect of both variables, though it was significant only for the former $(\mathrm{r}=-0.29, \mathrm{p}<0.001, \mathrm{~N}=53)$. NGL was negatively and significantly correlated with plant height $(\mathrm{r}=-0.32, \mathrm{p}<0.05, \mathrm{~N}=53)$ (Fig. 3).

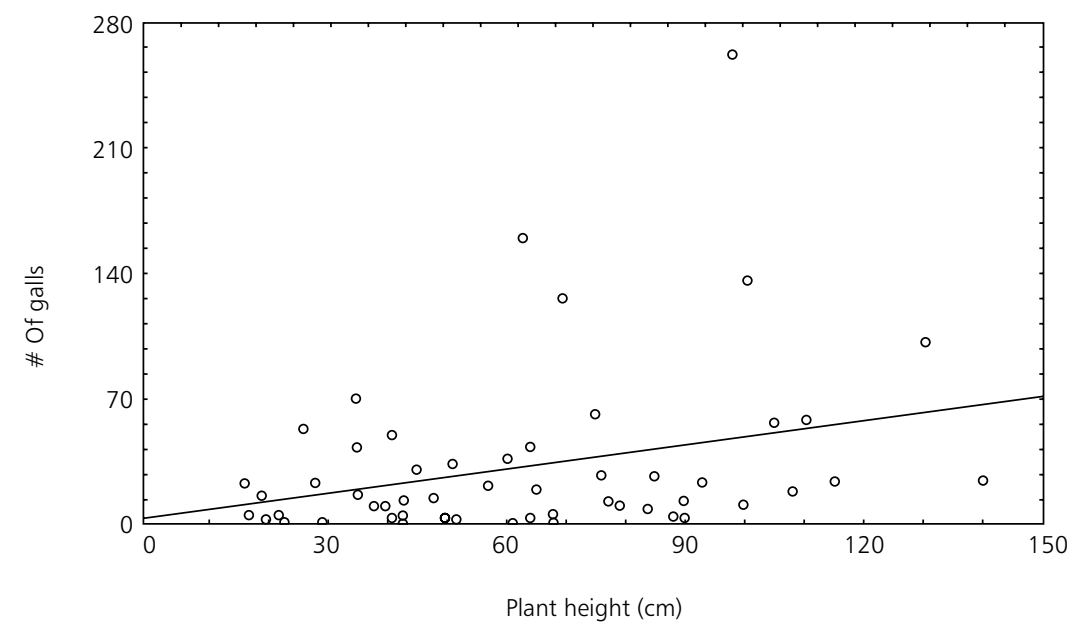

Fig. 2 - Linear regression between plant height and total number of galls per galled plant $(\mathrm{Y}=3,92+0,446 \mathrm{X}, \mathrm{r}=0.295$, $\mathrm{p}<0,05)$. 


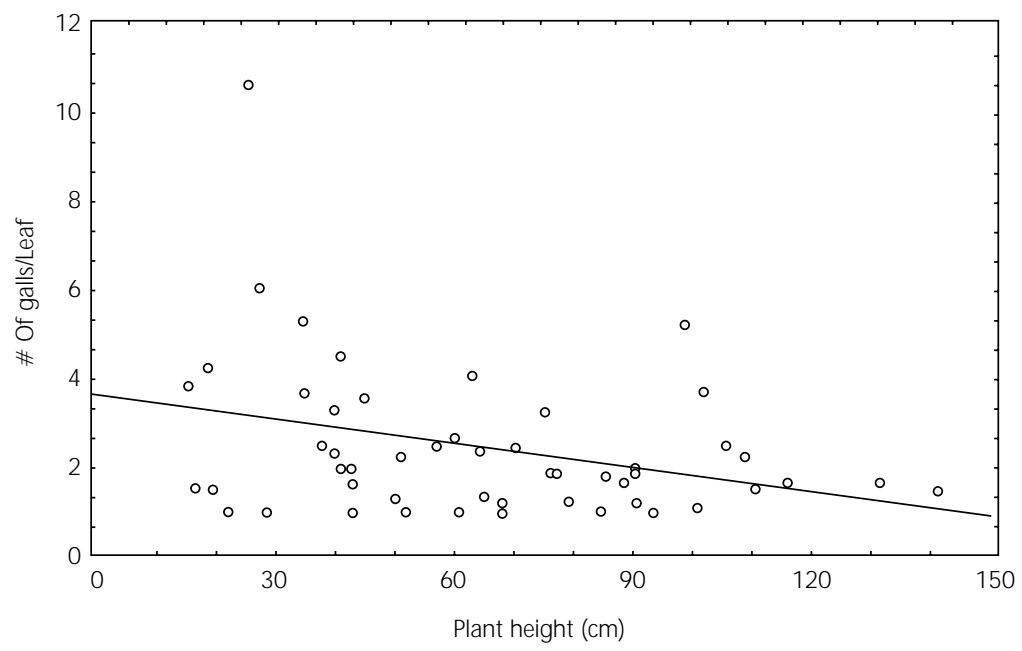

Fig. 3 - Linear regression between plant mean height and mean number of galls per leaf - NGL $\left(Y=3,65-0,018 X, r^{2}=\right.$ $-0.321, \mathrm{p}<0,05)$.

The relationship of NGL with number of bifurcations $(\mathrm{r}=-0.26, \mathrm{p}=0.06, \mathrm{~N}=53)$, and the summed effect of both variables $(r=-0.32, p=$ $0.06, \mathrm{~N}=53$ ) was also negative, though only marginally significant. NGL was positively and significantly correlated with FGL $(r=0.56, p<$ $0.001, \mathrm{~N}=53$ ). The index FGL did not differ significantly among the three size classes of host plants (ANOVA; $\mathrm{F}_{2,50}=2.45, \mathrm{p}=0.1$ ). NGL differed significantly among the three size classes of plants (ANOVA; $\mathrm{F}_{2,50}=5.68, \mathrm{p}<0.01$ ), decreasing as plant size class increased (Table 1). There was a significant difference in NGL between classes 1 and 2 (ANOVA; $F_{1,35}=7.30, \mathrm{p}<0.05$ ) and between classes 1 and 3 (ANOVA; $\mathrm{F}_{1,28}=$ $6.05, \mathrm{p}<0.05)$, but not between classes 2 and 3 (ANOVA; $\mathrm{F}_{1,37}=0.15, \mathrm{p}=0.7$ ). The percentage of galled plants did not differ between any pair of size classes $\left(X^{2}-\right.$ test; $p>0.05$ for all).

Isolated and non-isolated plants did not differ significantly in height (ANOVA; $\mathrm{F}_{1,76}=0.30, \mathrm{p}=$ 0.58 ), total number of galls per plant (ANCOVA; $\mathrm{F}_{1,1,50}=0.001, \mathrm{p}=0.97$ ), FGL (ANCOVA; $\mathrm{F}_{1,1,50}=$ $1.87, \mathrm{p}=0.18$ ), and percentage of galled plants $\left(\mathrm{X}^{2}=0.76 ; \mathrm{DF}=1 ; \mathrm{p}=0.38\right)$. Mean number of galls per leaf (NGL), on the other hand was significantly lower in isolated than in non-isolated plants (ANCOVA; $\left.\mathrm{F}_{1,1,50}=4.86, \mathrm{p}<0.05\right)($ Table 1$)$.

TABLE 1

Frequency of galled plants (in numbers and proportions) number of galls per leaf (NGL) for each size class of plants and for plants that are isolated or in 'patches' in two trails along an area of second-growth forest at Ilha Grande, Rio de Janeiro State, SE Brazil.

\begin{tabular}{|c|c|c|c|}
\hline & \# of galled plants (\%) & n & NGL (mean \pm 1 SD) \\
\hline \multicolumn{4}{|c|}{ Height classes } \\
\hline 1 (up to $40 \mathrm{~cm})$ & $15(55.6)$ & 27 & $3.72 \pm 2.57$ \\
\hline $2(41-80 \mathrm{~cm})$ & $24(70.6)$ & 34 & $2.12 \pm 0.99$ \\
\hline $3(>80 \mathrm{~cm})$ & $16(80.0)$ & 20 & $1.99 \pm 1.10$ \\
\hline \multicolumn{4}{|c|}{ Condition } \\
\hline Isolated & $8(57.1)$ & 14 & $1.57 \pm 0.78$ \\
\hline Non-isolated & $45(69.2)$ & 65 & $2.67 \pm 1.79$ \\
\hline
\end{tabular}




\section{DISCUSSION}

Ossaea confertiflora had a high frequency of galling by Lopesia brasiliensis, with nearly $70 \%$ of the observed individuals bearing galls. Galls occurred almost exclusively on leaves, aggreeing with the normal pattern of Neotropical cecidomyiid galls (approximately $70 \%$ of Neotropical galls and $50 \%$ of cecidomyid galls are induced on leaves; Mani, 1964). The number of galls per leaf varied greatly, though there was usually only one to three galls per leaf. Fernandes et al. (1988) observed great inter and intraspecific variation on the number of galls per leaf or leaflet in plants of several families at an anthropically disturbed area in the Brazilian state of Minas Gerais.

The total abundance of galls increased with plant height (which was significantly correlated with number of ramifications), aggreeing with the idea that larger host plants tend to harbor greater densities of phytophagous insects, as a result of an 'area per se' effect (Lawton, 1983; Strong et al., 1984). Nevertheless, only $8.7 \%$ of the variation in gall abundance was explained by plant height. A positive and significant correlation between host plant height and gall abundance has also been observed in studies of the leaf-galler Neopelma baccharidis (Homoptera: Psyllidae) on Baccharis dracunculifolia (Asteraceae) (Lara \& Fernandes, 1994; Collevatti \& Sperber, 1997), though plant height explained only $11 \%$ of the variance in gall abundance in the work of Lara \& Fernandes (1994) (statistics are not given in Collevatti \& Sperber, 1997). Several other factors (e.g. phenology, age, secondary compounds), other than physical dimensions, should be considered in the analysis of the variation in gall abundance per host plant (e.g. Horner \& Abrahamson, 1992; Lara \& Fernandes, 1994; Mopper \& Simberloff, 1995; Collevatti \& Sperber, 1997).

The fact that the absolute number of galled leaves per plant tended to increase with increasing plant size and/or number of ramifications was not surprising, since larger plants with more shoots usually have more leaves and, thus, more available resources for gallmakers. However, when we used an estimator of the relative density of galled leaves instead of the absolute density, the relationship became negative (though significant only with respect to number of ramifications). Also, the number of galls per leaf tended to decrease with increasing plant height and was positively correlated with the relative frequency of galled leaves per plant. Thus, relative intensity of galling in host plants and leaves tended to decrease with plant height and structural complexity, indicating that smaller plants are more intensely used by the gall-maker. Gallmakers usually prefer undifferentiated meristematic tissues as oviposition sites (e.g. Mani, 1964; Fritz et al., 1987; Price et al., $1987 \mathrm{a}, \mathrm{b})$, and younger, smaller plants have a greater relative concentration of optimal resources (i.e. young leaves) than older, many-branched ones. Moreover, galled leaves of some plants may suffer abscission. Since the probability of absicion likely increases with time, this would tend to eliminate evidences of past utilization of leaves by the gallmidge in older plants, and thus reduce the observed quantity of mature leaves with galls in such individuals. The oviposition strategy of the gallmaker could probably also have an effect: by dividing their ovipositions among more leaves, the gall-makers may spread the risk of attacks by parasitoids and predators (see Fernandes et al., 1988); in small plants, absolute availability of oviposition sites may be more reduced for gallmakers, resulting in more ovipositions per individual leaf. However, information about the biology and behavior of Lopesia brasiliensis (which is currently unavailable) is needed before any conclusions can be drawn.

The lower intensity of galling per leaf in isolated plants may result from the fact that isolated plants could be harder to find by gall-makers than plants in patches. However, the proportion of galled plants did not differ between isolated and "aggregated" plants, which would not be explained by the same logic. Also, galls were not found on some plants that were close to galled neighbors that belonged in the same size class. It should be taken into consideration, however, that the number of plants with close neighbors in our sample was more than four times greater than the number of isolated individuals (see Table 1), which makes the comparison less reliable. More information on the behavior of Lopesia brasiliensis and analyses of larger samples and more variables could help to clarify these patterns. 
Acknowledgments - This study is a portion of the results of the "Programa de Ecologia, Conservação e Manejo de Ecossistemas do Sudeste Brasileiro" of the Setor de Ecologia, Instituto de Biologia, UERJ. We thank C. Assunção, F. Hatano, I. Leite, A. Pinheiro and H. Póvoa for their help in the field and in data collection. We also thank the personnel of the Coordenadoria dos Campi Regionais (CCR) of UERJ and the Coordinator of the CEADS/UERJ, Isabel M. Gurgel, for local support and for making many facilities available at the study area. Maria Leonor del Rey Souza identified the host plant species. Raymond J. Gagné identified the gall midge. The second author benefitted from a Research Grant of the CNPq (Process \# 300 819-94-3).

\section{REFERENCES}

ARAÚJO, D. S. D. \& OLIVEIRA, R. R., 1988, Reserva Biológica Estadual da Praia do Sul (Ilha Grande, Estado do Rio de Janeiro): lista preliminar da flora. Acta Bot. Bras., 1: 83-94.

CRAIG, T. P., ITAMI, J. K. \& PRICE, P. W., 1989, A strong relationship between oviposition preference and larval performance in a shoot-galling sawfly. Ecology, 70: 1691-1699.

COLlEVATTI, R. G. \& SPERBER, C. F., 1997, The gall maker Neopelma baccharidis (Homoptera: Psyllidae) on Baccharis dracunculifolia DC. (Asteraceae): individual, local, and regional patterns. An. Soc. Entomol. Brasil., 26: 45-53.

DANSA, C. V. \& ROCHA, C. F. D., 1992, An ant-membracid plant interaction in a cerrado area of Brazil. J. Trop. Ecol., 8: 339-348.

DENNO, R. F. \& McCLURE, M. S., 1983, Variable Plants and Herbivores in Natural and Managed Systems. Academic Press, New York.

FAY, P. A., HARTNETT, D. C. \& KNAPP, A. K., 1996, Plant tolerance of gall-insect attack and gall-insect performance. Ecology, 77: 521-534.

FERNANDES, G. W., ARAÚJO, R. C., ARAÚJO, S. C., LOMBARDI, J. A., de PAULA, A. S., LOYOLA Jr., R. \& CORNELISSEN, T. G., 1997, Insect galls from savanna and rocky fields of the Jequitinhonha Valley, Minas Gerais, Brazil. Naturalia (S. Paulo), 22: 221-244.

FERNANDES, G. W., MARTINS, R. P. \& TAMEIRÃONETO, E., 1987, Food web relationships involving Anadiplosis sp. galls (Diptera: Cecidomyiidae) on Machaerium aculeatum (Leguminosae). Rev. Brasil. Bot., 10: 117-123.

FERNANDES, G. W. \& PRICE, P. W., 1991, Comparisons of tropical and temperate galling species richness: the roles of environmental harshness and plant nutrient status. pp. 91-115 In: P. W. Price, T. M. Lewinsohn, G. W. Fernandes \& W. W. Benson (eds.), Plant-Animal Interactions: Evolutionary Ecology in Tropical and Temperate Regions. Wiley \& Sons, New York.

FERNANDES, G. W. \& PRICE, P. W., 1992, The adaptive significance of insect gall distribution: survivorship of species in xeric and mesic habitats. Oecologia, 90: 14-20.
FERNANDES, G. W., TAMEIRÃO-NETO, E. \& MARTINS, R. P., 1988, Ocorrência e caracterização das galhas entomógenas na vegetação do campus Pampulha da Universidade Federal de Minas Gerais. Rev. Brasil. Zool., 5: 11-29.

FERREIRA, S. A., FERNANDES, G. W. \& CARVALHO, L. G., 1990, Biologia e história natural de Euphaleurus ostreoides (Homoptera: Psyllidae), cecidógeno de Lonchocarpus guilleminianus (Leguminosae). Rev. Brasil. Biol., 50: 417-423.

FRITZ, R. S., GAUD, W. S., SACCHI, C. F. \& PRICE, P. W., 1987, Patterns of intra- and interspecific association of gall-forming sawflies in relation to shoot size on their willow host-plant. Oecologia, 73: 159-169.

GAGNÉ, R. J., 1994, The Gall Midges of the Neotropical Region. Comstock, Ithaca, NY, 352p.

HORNER, J. D. \& ABRAHAMSON, W. G., 1992, Influence of plant genotype and environment on oviposition preference and offspring survival in a gallmaking herbivore. Oecologia, 90: 323-332.

HOUARD, C., 1933, Les Zoocecides des Plantes de L'Amérique du Sud et L'Amérique Centrale. Librarie Scientifique Hermann et Cia., Paris, 519p.

LARA, A. C. F. \& FERNANDES, G. W., 1994, Distribuição de galhas de Neopelma baccharidis (Homoptera: Psyllidae) em Baccharis dracunculifolia (Asteraceae). Rev. Brasil. Biol., 54: 661-668.

LAWTON, J. H., 1983, Plant architecture and diversity of phytophagous insects. Ann. Rev. Entomol., 28: 23-29.

MANI, M. S., 1964, Ecology of Plant Galls. Junk, The Hague, 434p.

MONTEIRO, R. F., FERRAZ, F. F. F., MAIA, V. C. \& AZEVEDO, M. A. P., 1994, Galhas entomógenas em restingas: uma abordagem preliminar. An. III Simpósio de Ecossistemas da Costa Brasileira, Vol. III, pp. 210-220.

MOPPER, S. \& SIMBERLOFF, D., 1995, Differential herbivory in an oak population: the role of plant phenology and insect performance. Ecology, 76: 1233-1241.

PRESZLER, R. W. \& PRICE, P. W., 1988, The effects of variable host quality on sawfly populations: a new approach to life table analysis. Ecology, 69: 2012-2021.

PRICE, P. W., ROININEN, H. \& TAHVANAINEN, J., 1987a, Plant age and attack by the bud galler, Euura mucronata. Oecologia, 73: 334-337.

PRICE, P. W., ROININEN, H. \& TAHVANAINEN, J., 1987b, Why does the bud galling sawfly, Euura mucronata, attack long shoots? Oecologia, 74: 1-6.

PRICE, P. W., COBB, N., CRAIG, T. P., FERNANDES, G. W., ITAMI, J. K., MOPPER, S. \& PRESZLER, R. W., 1990, Insect herbivore population dynamics on trees and shrubs: new approaches relevant to latent and eruptive species and life table development. pp. 1-38. In: E. A. Bernays (ed.), Insect-Plant Interactions, Vol. II. CRC, Boca Raton, Florida.

RIBEIRO, K. T., MADEIRA, J. A. \& MONTEIRO, R. F., 1998, Does flooding favour galling insects? Ecol. Entomol., 23: 491-494. 
STRONG, D. R., LAWTON, J. H. \& SOUTHWOOD, T. R. E., 1984, Insects on Plants: - Community Patterns and Mechanisms. Blackwell, Oxford.

THOMPSON, J. N., 1988, Evolutionary ecology of the relationship between oviposition preference and performance of offspring in phytophagous insects. Entomol. Exp. Appl., 47: 3-14.
WHITHAM, T. G., 1980, The theory of habitat selection: examined and extended using Pemphigus aphids. Amer. Natur.

ZAR, J. H., 1984, Biostatistical Analysis. Prentice-Hall, Englewood Cliffs, New Jersey, 718p. 